\title{
Review Article \\ Vital Autofluorescence: Application to the Study of Plant Living Cells
}

\author{
Victoria V. Roshchina \\ Laboratory of Microspectral Analysis of Cells and Cellular Systems and Optical Department Russian Academy of Sciences, \\ Institute of Cell Biophysics, RAS, Institutskaya Str. 3, Pushchino, Moscow Region 142290, Russia \\ Correspondence should be addressed to Victoria V. Roshchina, roshchinavic@mail.ru
}

Received 22 March 2012; Revised 18 June 2012; Accepted 16 July 2012

Academic Editor: Jin Zhang

Copyright ( 92012 Victoria V. Roshchina. This is an open access article distributed under the Creative Commons Attribution License, which permits unrestricted use, distribution, and reproduction in any medium, provided the original work is properly cited.

The application of various microscopy methods such as luminescence microscopy, microspectrofluorimetry and laser-scanning confocal microscopy has been considered as an approach to study the autofluorescence of plant living cells-from cell diagnostics up to modelling the cell-cell contacts and cell interactions with fluorescent biologically active substances. It bases on the direct observations of secretions released from allelopathic and medicinal species and the cell-donor interactions with cell-acceptors as biosensors (unicellular plant generative and vegetative microspores). Special attention was paid to the interactions with pigmented and fluorescing components of the secretions released by the cells-donors from plant species. Colored components of secretions are considered as histochemical dyes for the analysis of cellular mechanisms at the cell-cell contacts and modelling of cell-cell interactions. The fluorescence of plant biosensors was also recommended for the testing of natural plant excretions as medical drugs.

\section{Introduction}

The visible $(400-700 \mathrm{~nm})$ fluorescence of intact living cells (usually called autofluorescence) excited by ultraviolet, violet, or blue light is often observed under luminescence microscope $[1,2]$. Due to special microspectrofluorimeters or confocal microscope the fluorescence spectra of objects studied and the emission intensity can be also measured. Autofluorescence is the natural emission of cellular components due to a contribution of fluorescent compounds located in different cellular compartments. In general blue and green emission reflects the participation of universal cellular fluorophores NAD(P)H (max. $460 \mathrm{~nm}$ ), pterins (max. $450 \mathrm{~nm}$ ), and flavins (max. $520 \mathrm{~nm}$ ) [3], although in dry state weak blue fluorescence $(420-450 \mathrm{~nm}$ ) is also peculiar to isolated nucleotides, RNA, and DNA as well as some proteins, and seen in the films under luminescence microscope $[4,5]$, but water quenches the emission [4]. Besides, there are characteristic fluorescent compounds in various organisms [6]. In animal cells chitin (max. 450-460 and $520 \mathrm{~nm}$ ), collagen and elastin (max. 400-430, 465, 495 and $520 \mathrm{~nm}$ ) or cellulose (max. 420-430 nm) in plants, and fungi can also contribute in blue fluorescence [6]. Orange-red fluorescence depends on organism. In plant cells main known fluorophore used for environmental monitoring is chlorophyll with maximum 675-680 $\mathrm{nm}$ [7] and in photosynthesizing bacteria: bacteriochlorophyll [6]. Uroporphyrinogen and haemoglobin contribute in red lightening of mammalians, while green-red range emission may reflect a contribution of sea animal fluorescent proteins used for the genetic experiments as vector for the study of cellular components [6-8]. Terpenes, some alkaloids (colchicine) and flavonoids in plants, emit in blue or in blue-green (470-525 nm) region of the visible spectrum whereas polyacetylenes, isoquinoline, and acridone alkaloids emit in yellow and orange [8]. Red fluorescence of plant cells may be also due to anthocyanins and azulenes $(600-630 \mathrm{~nm})$ [8]. At ageing or, if the object being undergone ozone and relative reactive oxygen species, fluorescent pigments lipofuscins are formed that may emit in wider spectral range-from blue $(450-480 \mathrm{~nm})$ to red 
$(>600 \mathrm{~nm})$ in a dependence on the nature of the organism and duration of the exposure under unfavourable factor $[9,10]$.

Autofluorescence of the cellular compounds may serve (1) as markers for cytodiagnostics and (2) considerations of as natural indicator of cellular state because the emission often shows changes in cellular metabolism and responses to the external and internal signals [8]. This is true for the plant secretory structures analyzed under luminescent microscope (the structures are not seen in usual microscope without special histochemical staining) or laser-scanning confocal microscope (LSCM images) [8, 10, 20-22, 37-39]. The intensity and spectral composition of the emission differ in a dependence on, namely, (1) nature of the organism or (2) cell analyzed, (3) a taxonomic position of the organism tested, and (4) environmental and experimental conditions (actinic light, temperature, humidity, physiological state of a cell as a whole and phase of development, influence of neighbour cells or organisms, including parasites). Autofluorescence could be used (i) in express-microanalysis of the accumulation of the secondary metabolites in secretory cells without long biochemical procedures; (ii) in diagnostics of cellular damage; (iii) in analysis of cell-cell interactions [8, 10, 20, 21, 39].

In any case the phenomenon of autofluorescence could be used as a resource for the nondestructive vital microscopic analysis of natural organisms [41]. It has already practical application in various diagnostic procedures for cell biology analysis, ecology, medicine, and pharmacology. This paper considers the application of various types of luminescence microscopy to the study of plant cells, mainly such as secretory systems.

\section{Images and the Fluorescence Spectra of Fluorescing Cells in Cytodiagnostics}

Today our knowledge in the problem of autofluorescence, peculiar to living cells, mainly include results of experiments made on big plant cells that are suitable for observation both in vivo (such as in nature) and in vitro (in cultivated systems). Among similar objects are generative cells of flowers: pollen (male gametophyte) and pistil (female gametophyte) and nongenerative cells, such as plant vegetative microspores and special secretory cells. Some examples dealt with the application of luminescence microscopy in various modifications to analysis of the cells are shown on Figure 1. In particular there are the images seen under usual luminescence or confocal microscopes and the fluorescence spectra measured by microspectrofluorimeter or some types of confocal microscopes. We shall also comment about Figure 1 in sections below.

The research of fluorescence maxima in secretory cells showed the correlations and differences in the emission spectra excited by UV-light among the plant species studied and their specialized structures [8]. For example, nectaries mainly fluoresce, in blue region, while sporangia of fungi, mosses, horsetails, and ferns are in green-yellow (500$550 \mathrm{~nm}$ ). Except fungi, the structures have also maximum
$680 \mathrm{~nm}$ in red, peculiar to chlorophyll located in chloroplasts. Crystals of secretions emit more brightness than liquids. Today the secretion peaks were compared with the maxima of individual components of the same secretions in solutions or films $[5,8,10]$. Interference of various fluorophores in total emission may take place, but diagnostics of prevailing component of the secretion is real. Changes in the fluorescing compounds depend on stage of plant development, the influence of various factors-ozonation, redox agents and excretions of other organisms in the environment.

2.1. Pollen. Pollen is the unicellular structure (served for plant breeding of seed-bearing plants) that germinates on pistil stigma of flower forming pollen tube that grows within pistil style and carries out two spermia-male cells. As soon as the pollen tube achieves ovule (seed bag), here one sperm interacts with egg cell, and the fertilization is over by the embryo arising. Pollen often show visible autofluorescence excited by ultra violet or violet light. Luminescence microscope or laser-scanning confocal microscope was used for both the receiving fluorescing cell images and (in some cases) fluorescence spectra. Some examples of the emission are on Figure 1(a) and Table 1. Full information about the earlier studies of pollen autofluorescence as well as apparatuses for the observation and measurement has been summarized in reviews $[18,19]$ and monograph $[8]$. Here there are the references related to pioneers who first have seen autofluorescence of pollen under a luminescence microscope [43-45] and later measured first fluorescence spectra of pollen from various species $[46,47]$ with a microspectrofluorimeter.

Figure 1 shows the LSCM images of pollens (from medicinal plants) released fluorescing secretions from apertures, through which pollen tube enters at pollen germination. We see different colors of autofluorescence from pollen surface and drops of secretions (marked with arrows) released from apertures (green emission of the secretions from Solidago virgaurea, orange-red lightening from one of Calendula officinalis, and colourless from Oenothera biennis). Today the phenomenon of autofluorescence is applied to the various diagnostics seen from Table 1. First papers in this line dealt with analysis of the exine autofluorescence by luminescence microscope. Exine, the outer layer of pollen cover, consists of sporopollenin and in various species may include various fluorescent pigments from phenols and carotenoids up to azulenes and proazulenes $[8,15]$. Structure of exine was also analyzed with confocal microscopy [25], permitting to receive optical slices $[8,20,21,38,39]$, and the fluorescence spectra were also recorded $[8,15-19]$. Based on the autofluorescence the various steps in pollen development were studied $[8,13]$. Moreover, the phenomenon is applied to pollen classification $[30,31]$, including the search pollen grains of fruitful varieties from certain plant species [33]. For understanding of sporopollenin synthesis and exine assembly a simple effective genetic screen based on their autofluorescence characteristics was represented for the Arabidopsis thaliana pollen (the recovery of mutants with a variety of defects in exine structure) to identify genes involved in pollen exine production [34]. 


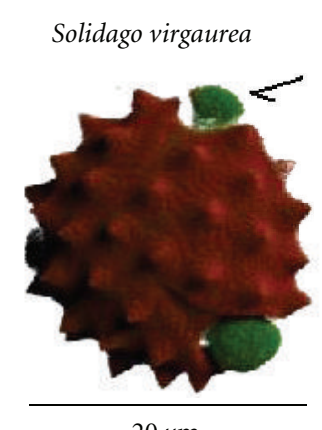

$20 \mu \mathrm{m}$
Calendula officinalis

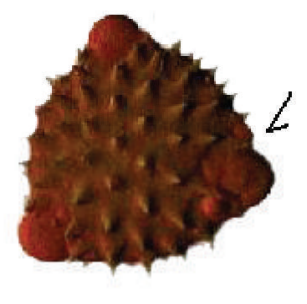

$100 \mu \mathrm{m}$

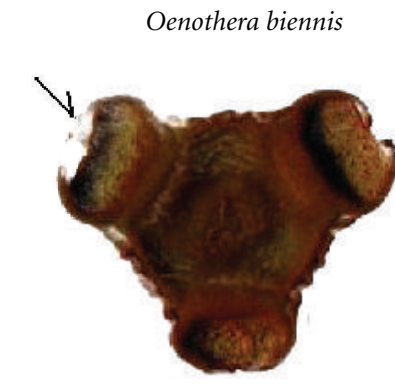

$100 \mu \mathrm{m}$
Cichorium intybus

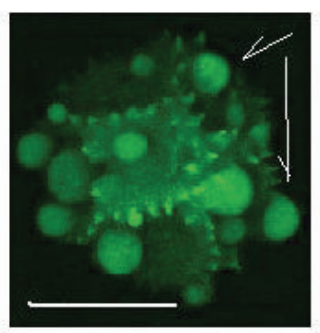

$10 \mu \mathrm{m}$

(a) Laser-scanning confocal microscopy of pollen

(A)
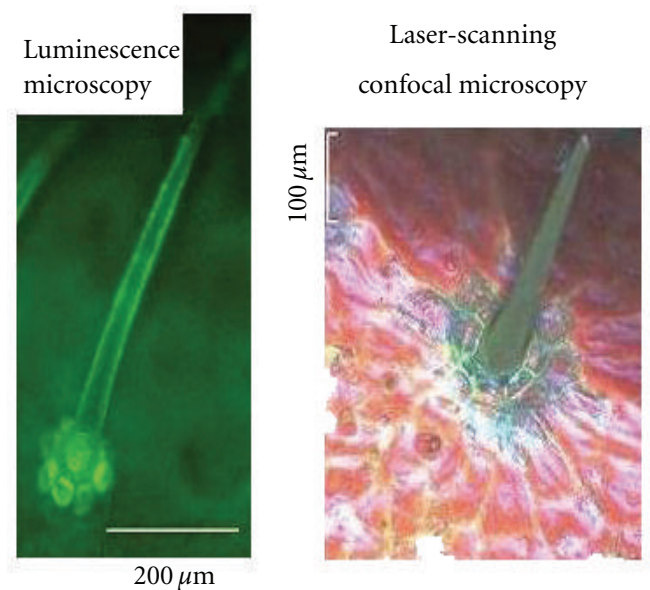

(b) Leaf secretory hair of Symphytum officinale

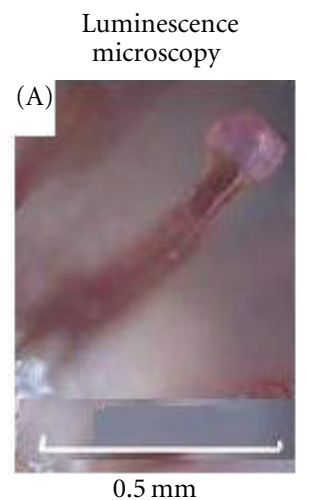

$0.5 \mathrm{~mm}$

Laser-scanning confocal microscopy
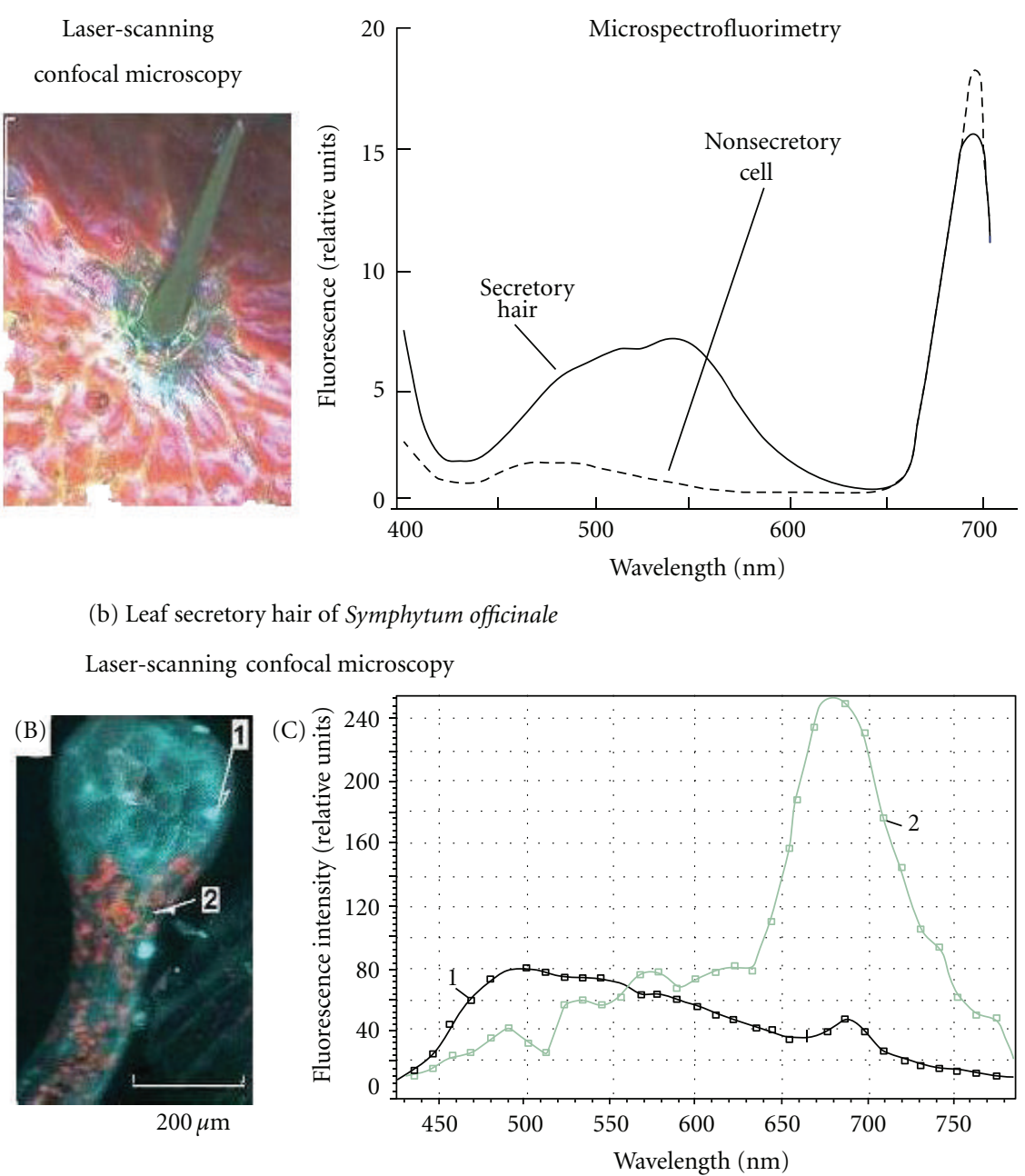

(c) Secretory hair on flower calyx from Rubus odoratus

FIGURE 1: Images and the fluorescence spectra of some intact fluorescing plant secreting cells. Source: adapted from [21, 22] and unpublished data of the review' author. (a) LSCM images of pollen grains from various species under confocal microscope LSM 510 NLO "Carl Zeiss" (Laser $488 \mathrm{~nm}$ ). Drops of secretions from apertures are seen. (b) and (c) Views of secretory hairs on leaf of comfrey Symphytum officinale and on the flower calyx of flowering raspberry Rubus odoratus under (A) luminescence microscope Leica 6000 (Excitation 360-380 nm) and (B) laser-scanning confocal microscope Leica TSC SP 5 (laser $405 \mathrm{~nm}$ ) and the (C) fluorescence spectra measured by registered microspectrofluorimeter MSF-1 (Excitation 360-380 nm) or laser-scanning confocal microscope Leica TSC SP 5 from secretory head with released secretion (1) and stalk (2) of secretory hair. 
TABLE 1: Autofluorescence in pollen diagnostics (LM-Luminescence microscopy, MS—Microspectrofluorimetry, LSCM-Laser-scanning confocal microscope).

\begin{tabular}{|c|c|c|}
\hline Diagnostics & Microscopic method & Fluorescence characteristics \\
\hline $\begin{array}{l}\text { Vital pollen characteristics. Changes in the autofluorescence of the } \\
\text { pollen wall during microsporogenesis and chemical treatments } \\
{[11,12]}\end{array}$ & LM, MS & Color and fluorescence spectra \\
\hline Wall development of sterile and fertile pollen [13] & LM & Color \\
\hline Assessment of pollen retention using exine autofluorescence [14] & LM & Images \\
\hline Matured and non-matured pollen [15-19] & MS & $\begin{array}{l}\text { Fluorescence spectra (pigment } \\
\text { composition) }\end{array}$ \\
\hline Self-incompatibility and self-compatibility of pollen [17] & MS & $\begin{array}{l}\text { Fluorescence spectra (pigment } \\
\text { composition) }\end{array}$ \\
\hline Pollen loads analysis as well as pollen-derived products of bees $[8,17]$ & MS & $\begin{array}{l}\text { Fluorescence spectra (pigment } \\
\text { composition-azulenes, carotenoids) }\end{array}$ \\
\hline Pollen-pollen interactions in the mixtures $[8,20-23]$ & LSCM, MS & $\begin{array}{l}\text { Changes in the fluorescence spectra of } \\
\text { pollen from different species reflect } \\
\text { changes in pigments' state }\end{array}$ \\
\hline Pollen viability $[8,17]$ & MS & Fluorescence intensity after moistening \\
\hline Pollen-pistil interaction at fertilization $[8,17,24]$ & MS & $\begin{array}{l}\text { Changes in the fluorescence spectra } \\
\text { reflect the receptor state }\end{array}$ \\
\hline Exine structure [25] & LSCM & Images \\
\hline Quantifying dynamics of pollen shed [26] & LM & Images \\
\hline Ozone damages [27-29] & MS & $\begin{array}{l}\text { Changes in the fluorescence spectra } \\
\text { reflect pigments' state and forming } \\
\text { pigment of aging lipofuscin }\end{array}$ \\
\hline Damages by reactive oxygen species $[28,29]$ & MS & Changes in the fluorescence spectra \\
\hline $\begin{array}{l}\text { Classification of pollen grain species using autofluorescence image } \\
\text { analysis }[30,31]\end{array}$ & LM & $\begin{array}{l}\text { Images and blue/red autofluorescence } \\
\text { ratio }\end{array}$ \\
\hline $\begin{array}{l}\text { Testing in nanotechnology: Commercially produced fullerene fine } \\
\text { particles [32] }\end{array}$ & LM & $\begin{array}{l}\text { Adhesion of nanoparticles estimated on } \\
\text { the autofluorescence intensity changes }\end{array}$ \\
\hline The search of fruitful varieties from certain plant species [33] & LSCM & Images \\
\hline $\begin{array}{l}\text { Genetic screen to identify genes involved in pollen exine production } \\
\text { [34] }\end{array}$ & LSCM & $\begin{array}{l}\text { Wild-type exine fluoresces with two peaks } \\
460 \mathrm{~nm} \text { (higher) and } 505 \mathrm{~nm} \text { (lower) }\end{array}$ \\
\hline $\begin{array}{l}\text { A novel screen identifies multiple pollen mutants that have defective } \\
\text { exine [34] }\end{array}$ & LSCM & $\begin{array}{l}\text { Defective mutants differ in the emission } \\
\text { intensity in the above-mentioned peaks }\end{array}$ \\
\hline Taxonomic classification of pollen [35] & LSCM & Images \\
\hline Pollen concentration in air $[6,36]$ & LM, LSCM & Images, emission intensity \\
\hline
\end{tabular}

The fluorescence spectra of pollen from 20 plant species, both wind-and insect-pollinated, were analyzed [8]. Pollen grains from wind-pollinated species (birch, pine and others) have mainly blue fluorescence whereas insect-pollinated ones belonged to different species-in blue, yellow, green, or bluegreen. Nonmatured pollen demonstrated red fluorescence due to the presence of chlorophyll, while matured grains changed the color of the emission. The autofluorescence spectra of many pigmented and colorless pollens treated with ozone in various concentrations was also studied, and some characteristic damages were shown [27-29]. The fluorescence maximum at 530-550 nm disappeared in carotenoidcontaining pollen grains of Philadelphus grandiflorus and Epiphyllum hybridum, and a new maximum at $475-480 \mathrm{~nm}$ 
arose (unlike carotenoid-less pollen of Plantago major) that correlated with lipofuscin-like substances observed in the extracts from the pollen grains [27-29].

In pollen mixtures changes in the fluorescence of pollens from different species may reflect their chemical (allelopathic) relations $[8,21]$. LSCM images directly demonstrated the alterations in the emission and the state of pollen grains from Field Scabious Knautia arvensis (L.) Coult. (Dipsacaceae) contacting with pollen from wormwood Artemisia absinthium L. (Linn.) (Asteraceae) [20].

The autofluorescence imaging alone or in a combination with other morphological parameters [33] can be considered as nondisruptive method for pollen classification since it does not require any treatment of fixing or staining of the specimens. Therefore, this simple and fast method can be used for pollen counting and taxonomical classification in multiple applications that concern disciplines like aerobiology for identification of pollens in bioaerosols $[6,36,48$, $49]$. Today the pollen study is very important, because airoccurring pollen from certain plant species may induce allergy, although on the other side pollen grains of medicinal plants are used for drug preparation. Knowledge of pollen state is necessary for analysis of plant fertility in genetics and biotechnology or of the meteorological situation in ecological monitoring as well as in pharmacy.

2.2. Pistil. Pistil of flower is female gametophyte which stigma receives chemosignal from pollen as male gametophyte and recognizes pollen grains from the same plant species (as well as self-compatible or self-incompatible pollen of the species) or from foreign species. Autofluorescence reflects the pistil state before pollen application and after the pollen grains addition on pistil stigma $[8,17,24]$. If selfpollination occurs one can see changes in the peaks positions and the emission intensity in a comparison with the pistil fluorescence reply on pollen that originates from another plant of the same species like was seen on the example with Hippeastrum hybridum $[16,17]$. When foreign pollen was applied to the pistil stigma often there are no changes in the pistil fluorescence [8]. Moreover pistils from self-compatible and self-incompatible lines of the one and same plant species, in particular as in Petunia hybrida clones, have different maxima in the fluorescence spectra [8].

\subsection{Secretory Cells-Donors of Biologically Active Fluorescing} Compounds. Any living cells may form and release secretions out, and it is better seen in specialized secretory plant cells with fluorescent products $[8,10]$. Images of the secreting cell fluorescence excited with ultraviolet or violet light are especially valuable in allelopathic and medicinal plants which contain compounds named allelochemicals (simultaneously being valuable pharmaceuticals) in secretory cells [50]. Many of the chemicals excreted act on the other organisms in biocenosis. The secretory cells often show bright fluorescence at the excitation of ultraviolet $(360-390 \mathrm{~nm})$ or violet $(400$ $430 \mathrm{~nm}$ ) light $[8,10,51,52]$ due to the presence of phenols, alkaloids, terpenoids, etc.). The fluorescing images of similar cells - glandular hairs of leaf and flower-are shown under usual luminescence and confocal microscopes as seen on Figures 1(b) and 1(c). Leaf secretory hair of comfrey Symphytum officinale from family Boraginaceae under the violet or bluegreen excitation (the structures weakly lighten at the ultraviolet) has the green-yellow emission maximum $550 \mathrm{~nm}$ and shoulder $460-500 \mathrm{~nm}$ in the fluorescence spectrum. Another plant species-purple flowering raspberry Rubus odoratus shows the emission of calycinal secretory hair on flower in blue-green with maximum $475 \mathrm{~nm}$ unlike nonsecretory stalk cells that have maximum $675-680 \mathrm{~nm}$, peculiar to chlorophyll.

The images and the emission intensity of secretory cells included fluorescent drugs is important for medicinal plant species because this may characterise the state of pharmaceutically valuable material [40] as shown in Table 2 for fresh and dried leaves of warmwood Artemisia species (in pharmacy used as tonic, stomachic, febrifuge, and antihelmintic and a good remedy for enfeebled digestion and debility). The species contained fluorescent terpenes, sesquiterpenes and phenols [8]. The green emission of secretory cells on fresh leaves of wormwood A. absinthium L. was about 4 times higher, than in non-secretory cells. In dried material the difference increased significantly up to 20 times. This demonstrates a difference in the fluorescence intensity between secretory cells of fresh leaves than in dried leaves. In mugwort $A$. vulgaris $\mathrm{L}$. dried leaf secretory cells emitted 2 times brightly in a comparison with secretory cells of fresh material. The visible difference in the fluorescence intensity between two species reflects the difference in an accumulation of fluorescent pharmaceuticals (azulenes and flavonoids) [40]. Flavonoids and coumarins as fluorophores may be also included in the leaf fluorescence of $A$. vulgaris.

\section{Images of Fluorescent Plant Secretory Cells in Cell-Cell Interactions}

Cytodiagnostics of cell-cell interactions has perspectives also in the analysis of autofluorescence in the studies of chemical relations (allelopathy) between species in biocenosis relations). The examples may be a visualization of the insect attack [53] or fungal invasion [54-57] and relationships between pollen grains of different species [20, 21]. Fungi or insects such as ticks, spiders, or human skin fluoresce, mainly, in blue $(460-470 \mathrm{~nm})$ or blue-green $(<520-530 \mathrm{~nm})$ whereas muscle-in blue with maxima 410 and $480 \mathrm{~nm}$. Insects fluoresce by all parts of their body, and it may observe separately on the plant cell surface. The blue emission intensity of fungal hypha and mycelium are much higher than in fluorescing secretory plant cells that makes possible to recognize fungal infection.

3.1. The Parasitive Invasion. Figure 2 demonstrates the example for leaf of medical plant mint Mentha piperita used by aphid for nutrition. On the leaf colorless microscopic larvae are plant-louse not seen well up to the excitation by actinic light of luminescence microscope. Blue-fluorescing Mentha gland (if excited by UV-light) with maxima 475 , $540,675-680 \mathrm{~nm}$ in the fluorescence spectrum is covered by 
TABLE 2: The fluorescence intensity ( $I$ ) of leaf secretory cells of medicinal plants Artemisia absinthium and Artemisia vulgaris measured by double-beam microspectrofluorimeter MSF -2 at 520-540 nm or at 640-680 nm. Source: [40]. Excitation $420 \mathrm{~nm}$.

\begin{tabular}{llcr}
\hline Cell & Plant material & $I_{520-540}$ & $I_{640-680}$ \\
\hline & \multicolumn{1}{c}{ Artemisia absinthium } & & $5.76 \pm 0.9$ \\
Glandular cell and hair & Fresh leaves & $0.84 \pm 0.07$ & $7.99 \pm 1.0$ \\
Nonsecretory cells & Fresh leaves & $0.21 \pm 0.01$ & $3.15 \pm 0.08$ \\
Glandular cell and hair & Dried leaves & $0.28 \pm 0.01$ & $2.28 \pm 0.03$ \\
Nonsecretory cells & Dried leaves & 0.01 & $2.26 \pm 0.09$ \\
\hline & Artemisia vulgaris & & $4.89 \pm 0.20$ \\
Glandular cell and hair & Fresh leaves & $0.12 \pm 0.01$ & $1.83 \pm 0.08$ \\
Nonsecretory cells & Fresh leaves & $0.04 \pm 0.01$ & $2.40 \pm 0.5$ \\
Glandular cell and hair & Dried leaves & $0.26 \pm 0.02$ & $0.14 \pm 0.01$ \\
Nonsecretory cells & Dried leaves & & \\
\hline
\end{tabular}

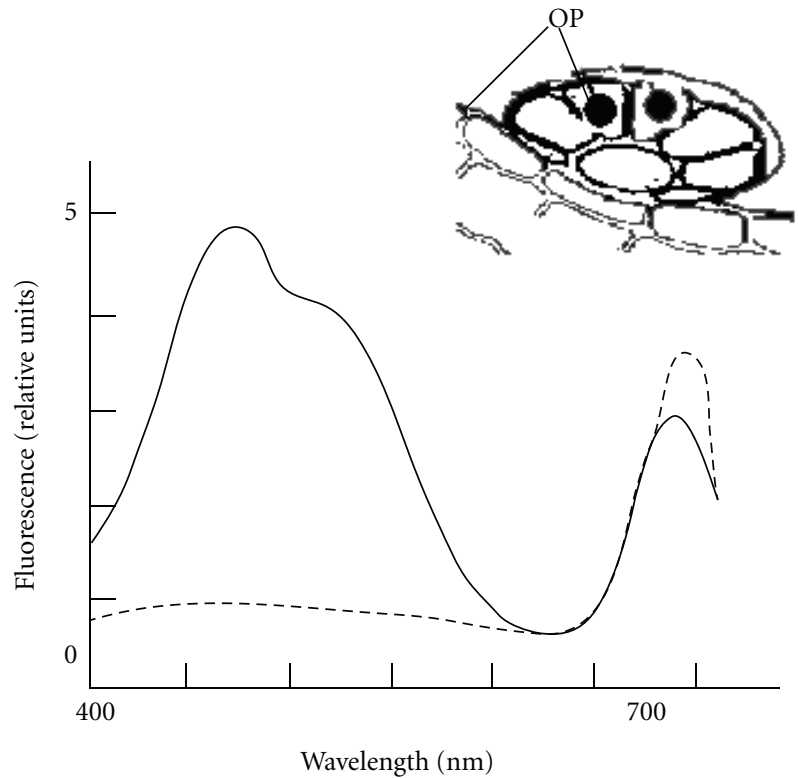

(a)

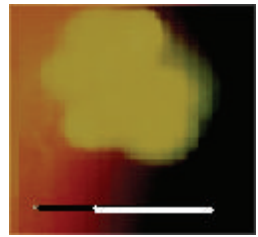

$70 \mu \mathrm{m}$

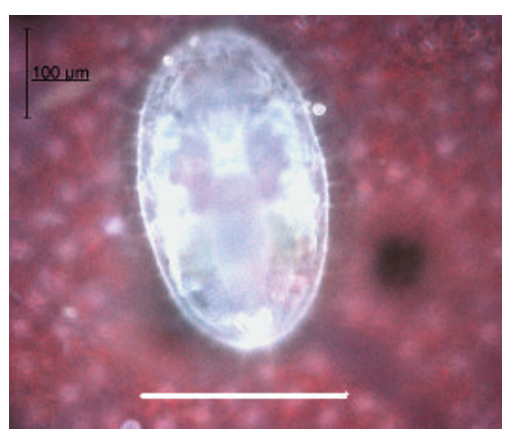

$100 \mu \mathrm{m}$

(b)

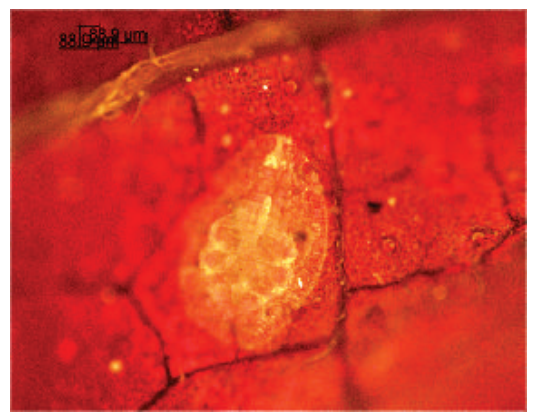

(e)

(c)

(d)

Figure 2: Fluorescent larva of aphis interacts with cellular complex of leaf gland of mint Mentha piperita. (a) Left: the fluorescence spectra of secretory cells measured by microspectrofluorimeter MSF-1. Excitation: 360-380 nm. Unbroken line-secretory cells; broken line nonsecretory cells. The position of optical probe (OP) is shown. Right: the common view of gland under luminescence microscope "Carl Zeiss CD-28". ((b)-(e)) Images under luminescence microscope Leica DM 6000. (b) The common view of aphis larva out of the gland, ((c)-(e)) views of larva on the mint gland. Excitation by light 360-410 nm (b), 420-450 nm (c), $480 \mathrm{~nm}$ (d), and $560 \mathrm{~nm}$ (e). 
weak blue-fluorescing aphis larva (chitin emission, mainly at $450 \mathrm{~nm}$ ). At excitation by violet or green-yellow light yellowfluoresced mint gland (surrounded by red fluorescing nonsecretory cells of leaf mesophyll due to chlorophyll presence) mainly was seen through nonvisible (transparent) larva body.

Many pathogenic and saprophytic fungi fluoresce in blue green (in 390-490 nm spectral region) under actinic ultraviolet light [54-57]. Moreover the phenomenon was better seen under stress (desiccation, heat, chemicals) [56]. Recently blue-green autofluorescence of fungi of Ustilago maydis on maize and cell wall of this plant is an indicator of the invasion [57]. At the fungal infection the value of autofluorescence as a screening method for detecting fungi in tissues was compared with conventional histochemical stains. Autofluorescence can be used as a rapid screening method for identification of fungi in tissue sections as it does not require any other specialized staining procedure. Confocal microscopy appears to be more suitable for plantpathogen interaction in details [58]. Fungal fluorophores may depend on species and are not well studied yet. Today fungal infection is better registered observing the enhanced blue-green autofluorescence of plant cell walls related to their phenols and sometimes auxin exchange [59].

3.2. Pollen-Pollen Interactions. Special interest is the visualization of the interaction between pollen grains of various species that named as pollen allelopathy. At the contact, excretion from pollen-donor acts as chemosignal on pollenacceptor, inducing the changes in the fluorescence of the microspores and their germination. The interaction of big pollen from Knautia arvensis (fluorescing in green) and small pollen grains from Artemisia absinthium or from Solidago virgaurea, which have released drops of red-fluorescing secretion as seen under laser-scanning confocal microscope $[8,20,21]$. This secretion was seen on the surface of nongerminated pollen from Knautia arvensis and also on the surface of pollen tubes. The interaction of green fluorescent pollen of $K$. arvensis and red-fluorescing secretion of pollen from Artemisia absinthium decreased the germination in both contacting types of microspores. In this case, perhaps, the enhancement in fluorescence is related to the energy loss peculiar to nonviable pollens. On LSCM images of fluorescent pollens in their mixtures red-fluorescing secretion for large pollen of Oenothera biennis contacted with small pollens of Matricaria chamomilla emitted in green and liberated green-fluorescing secretions were seen [21]. Optical slices showed the interior of contacted pollen grains, green fluorescence was seen only on the surface of $M$. chamolilla microspore, while red emission was also seen inside the pollen grain of O. biennis. LSCM images of fluorescent pollen made it possible to observe directly (i) the contact of intact cell, (ii) changes in their emission, and (iii) location of contacting secretions.

Intensity of autofluorescence from interacting cells in pollen mixtures also reflects the mutual influence of contacted secretions as shown for microspores from Hippeastrum hybridum, Philadelphus grandiflorus, Knautia arvensis,
Plantago major, and Oenothera biennis used as pollenacceptors, while other pollen grains from 42 plant speciesas donor pollens [21]. Change of the light emission (excited by UV $360-380 \mathrm{~nm}$ or violet $430 \mathrm{~nm}$ light) is a visual chemical response to the pollen excretion from foreign pollens. To develop models for pollen-pollen interactions, the effects of allelochemicals secreted by foreign pollen (i.e., donor pollen) were studied in vitro or in vivo on autofluorescence concerned with the germination of acceptor-pollen [21]. Autofluorescence of acceptor and donor pollens in mixtures was changed to blue-green and red spectral regions that may serve as the indicator reply on foreign microspores. Generally increased blue-green and occasionally red emission indicated the decrease in the rate of pollen germination. However, red fluorescence was not related to germination and depended, mainly, on species used. It may be explained by redox changes in pollen components (often cover constituents) or by the synthesis of new fluorescing metabolite. Perhaps, the enhancement in blue-green emission of pollen could be related to the formation of fluoresced Schiff bases or to the formation of $\mathrm{NAD}(\mathrm{P}) \mathrm{H}$ emitted with maxima $460 \mathrm{~nm}$. Red fluorescence of matured pollen is often correlated with the presence of anthocyanins or azulenes like occurs in overgrown parts of plants $[8,21]$.

\section{Autofluorescence as Biosignal or Marker to Study Localization of Secondary Metabolites}

Even 50 years ago Frey-Wyssling and Agthe have discovered fluorescence of flower nectar [8], as possible signal for insects-pollinators [60], and today the phenomenon has been demonstrated for various floral and extrafloral nectaries [8]. Moreover, some secondary metabolites served as the defense agents against parasitive invasion, for example, phenols emit under the excitation of UV-light [3], and their autofluorescence should mark their location in cells and tissues [61-63].

4.1. Biosignal for Insects. New look on autofluorescence appears with several works dealt with the search of signal for pollinators which prefer flowers of the certain plant species $[64,65]$. A quantitative evaluation of the light emerging from intact petals of Rhododendron indicum flowers of different colors was performed based on the measurement of reflectance and fluorescence emission. Emitted photons as fluorescence were compared with reflected photons. The fluorescence quantum yield values $\left(\phi_{f}\right)$ varied from $7.6 \times$ $10^{-5}$ to $6.3 \times 10^{-4}$ for the emission in the blue region of the electromagnetic spectrum and from $2.4 \times 10^{-5}$ to $1.9 \times 10^{-4}$ for the emission in the red one [64]. $\left(\phi_{f}\right)$ was calculated for flowers of Bellis perennis (white, yellow, pink, and purple), Ornithogalum thyrsoides (petals and ovaries), Limonium sinuatum (white and yellow), Lampranthus productus (yellow), Petunia nyctaginiflora (white), Bougainvillea spectabilis (white and yellow), Antirrhinum majus (white and yellow), Eustoma grandiflorum (white and blue), Citrus aurantium (petals and stigma), and Portulaca grandiflora (yellow) [65]. The highest values were obtained for the ovaries of 
O. thyrsoides $\left(\phi_{f}=0.030\right)$ and for Citrus aurantium petals $\left(\phi_{f}=0.014\right)$ and stigma $\left(\phi_{f}=0.013\right)$. The fluorescence emission as an optical signal in biocommunication was negligible if to compare to the light reflected by the petals. Nevertheless, the calculation of quantum catches for each studied flower species described the visual sensitization of insect eye photoreceptors.

4.2. Localization of Secondary Metabolites in Cells and Tissues. Location of secondary metabolites fluoresced under UV or violet excitation is a new approach to visualize secondary metabolites in plants [61-63, 66-70]. Among the compounds are fluorescent phenol compounds that play a major role in the interaction of organisms in biocenosis attracting insects and functioning as signals between plants (allelopathy), as signals between plants and phenols in cell walls, vacuoles, and associated with $\mathrm{N}_{2}$-fixing bacteria or pathogenic organisms [61-63]. The distribution of flavonoids such as anthocyanins in grape (Vitis vinifera L.) was measured nondestructively by chlorophyll fluorescence imaging using two excitation light bands at 550 and $650 \mathrm{~nm}$ [62]. Strong blue autofluorescence of living young leaf of Coffea canephora, species which contains very high level of chlorogenic acid, relates to vesicles filled with the compound and where the similar emission was also observed [63]. The phenol localization in the vacuole of epidermis cells, in vesicles and chloroplasts of mesophyll cells strengthen the hypothesis of its involvement in leaf protection against UV damages or pathogens. Besides phenols, yellow pigments betaxanthins also fluoresce in flowers in green region [66] and according the emission it is possible to determine dopamine-pigment complex in living Portulaca oleracea cells [67].

Especial attention was paid to localization in cells and tissues such flavonoids as anthocyanins in grape and apples $[68,69]$. Practical tendency in the investigations is the use of multiparametric fluorescence sensor in apple quality [69]. The pixel intensity in the derived logarithm of the fluorescence excitation ratio image was directly related to the anthocyanin concentration of berry extracts. The method will be useful for the assessment of the heterogeneity of anthocyanin accumulation in berries depending on physiologic and climatic factors. It can also represent a new, rapid and noninvasive technique for the assessment of fruit ripening and the appropriate time of harvest. Moreover, wellseen autofluorescence of the anthocyanins is recommended for their traffic within cell [70]. The detection of pigments and colorless flavonoids can provide a useful indication of fruit quality $[68,69]$ or to localize some phenols such as chlorogenic acid in leaf tissues, demonstrating the great potential of multiphoton microscopy combined with spectral deconvolution [63].

\section{Autofluorescence of Biosensors}

Due to their autofluorescence plant intact cells may serve as biosensors and bioindicators because they have natural structure that determinates their high activity and stability
[71]. Criteria in the screening of the plant cells as biosensors for biologically active compounds should be as follows: (1) the object use is easy in laboratory and in the field and (2) autofluorescence should be one of the physiological responses on the external chemicals because reflects the fast biochemical changes. They could serve as the biosensors of some biologically active excretions (having drugs' characteristics) from plants known as weeds, medicinal, or poisonous plant species [37, 42, 71]. Plant biosensors are more suitable for similar testing, than animals, which use needs procedures of vivisection $[40,71]$.

5.1. Characteristics of Biosensors. As unicellular biosensors vegetative microspores of spore-bearing plants and pollens of seed-bearing plants $[8,42,71]$ may be used as well as multicellular biosensor-pistil stigma in flowers $[8,24]$.

Figure 3 shows examples of fluorescent analysis of vegetative microspores of horsetail Equisetum arvense using various technique. Under luminescence microscope, green fluorescence of cell wall and elaters (shell employees to attach microspore to the substrate) is visible. Through the rather transparent cover bright red fluorescence of chloroplasts, located inside the cell among nonlightening cytoplasm, is also observed. The total spectra of fluorescence from cells measured by microspectrofluorimeter depended on the presence of appropriate pigments and had the three peaksin blue with maximum 450-460 nm (azulenes, phenols), in green with maximum $540-550 \mathrm{~nm}$ (carotenoids), as well as the most intense red emission with maximum $675-680 \mathrm{~nm}$ (chlorophyll). Cell cover liberated during the microspore development does not have a maximum in red spectral region [72]. Average fluorescence intensity of 100 cells measured on the one subject slide by dual-beam microspectrofluorimeter in green $(520 \mathrm{~nm})$ and red $(640-680 \mathrm{~nm})$ was differed in many times as seen from numerical data of summary emission shown in the histogram area ( 3.15 relative units in red against 0.13 relative units in green region). Red emission prevailed. Its intensity increases during the microspore development in comparison with dry rest (nondeveloped) cells $[72,73]$.

If the division of the spore cell occurs (and duplication of chloroplasts takes place) the 2 times increase in red fluorescence is the indicator of cellular division because amounts of chloroplasts and fluorescing chlorophyll are doubled. Unlike the microspectrofluorimetry laser-scanning confocal microscopy permits to see images of optical slices of intact microspore cells at different depths and register the spectra of fluorescence from individual parts (marked as numerals on Figure 3), namely, cell wall, including its outer layer exine (1), its inner layer intine with plasmalemma (2), and chloroplasts (3).

The natural fluorescence of pollen and pistils as biosensors is served to study of various processes [10, 21, 22, 24, 27-29] from the damages by ozone and other reactive oxygen species to chemosignaling. Indicators of the emission (Table 3) based on color and intensity of fluorescence altered under ozone and reactive oxygen species or the addition 
TABLE 3: Pollen biosensors.

\begin{tabular}{llll}
\hline Plant species & $\begin{array}{l}\text { Colour of pollen } \\
\text { autofluorescence }\end{array}$ & $\begin{array}{l}\text { Prevailing } \\
\text { fluorophore }\end{array}$ & Indicator reaction \\
\hline $\begin{array}{l}\text { Hippeastrum hybridum } \mathrm{L} . \\
\text { (Herb), knight's star } \\
\text { (Amaryllidaceae) }\end{array}$ & Blue-green & Flavins, phenols & $\begin{array}{l}\text { Shifts in the fluorescence maxima and } \\
\text { intensity at pollen-pistil or pollen-pollen } \\
\text { interactions and neurotransmitters } \\
\text { additions }[8,16,17,19,21,23]\end{array}$ \\
$\begin{array}{l}\text { Philadelphus grandiflorus, } \\
\text { wild mock-orange } \\
\text { (Hydrangeaceae) }\end{array}$ & Yellow-orange & $\begin{array}{l}\text { Carotenoids, } \\
\text { azulenes, } \\
\text { anthocyanins }\end{array}$ & $\begin{array}{l}\text { Shifts in the fluorescence maxima and } \\
\text { intensity after ozone or other reactive } \\
\text { oxygen species treatment [26-28] }\end{array}$ \\
$\begin{array}{l}\text { Coult., field scabious } \\
\text { (Dipsacaceae) }\end{array}$ & Green & Anthocyanins & $\begin{array}{l}\text { Shifts in the fluorescence intensity at } \\
\text { pollen-pollen interactions [20, 21] }\end{array}$ \\
\hline
\end{tabular}

Luminescence microscopy
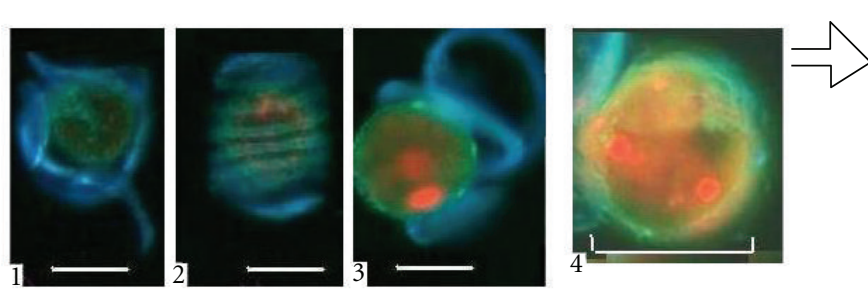

Microspectrofluorimetry

The fluorescence spectrum

Histograms

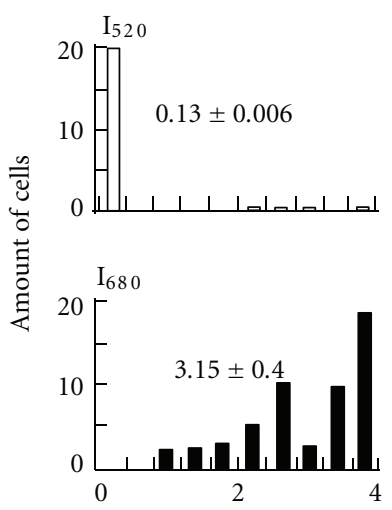

Laser-scanning confocal microscopy
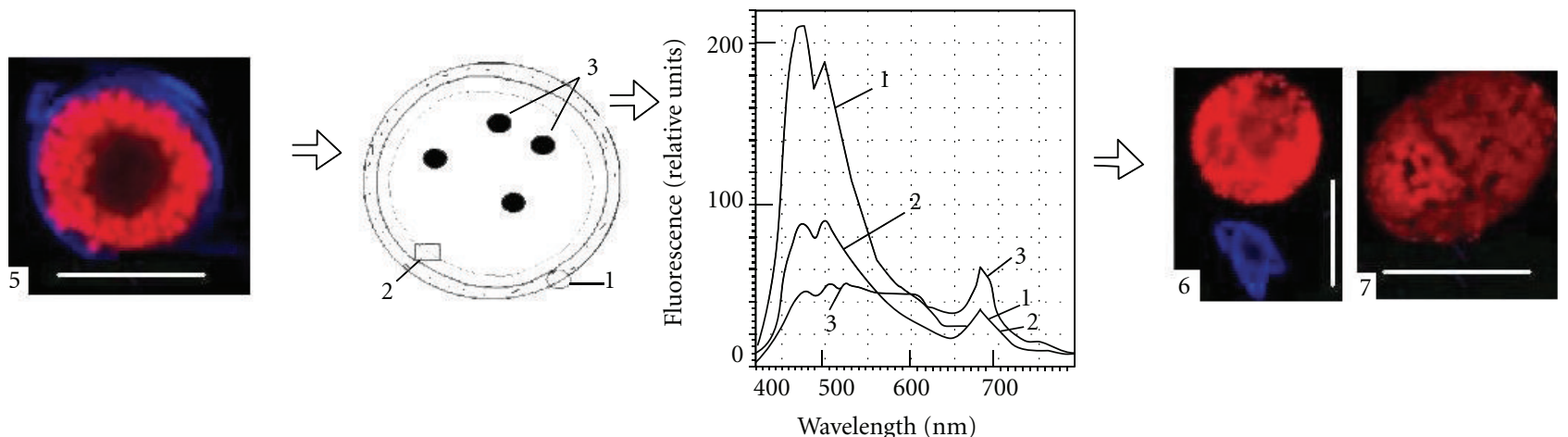

Figure 3: The images and fluorescence spectra of the vegetative microspores of horsetail Equisetum arvense. Sources: [8, 42] and nonpublished data of author. Upper side: Luminescence microscopy (left). Views (1-4) under the luminescence microscope Leica 6000. Microspectrofluorimetry. The fluorescence spectrum (middle) and the emission intensity distribution in form of numerical data or histogram (right). The fluorescence intensity $(I)$ on histograms measured by dual-wavelength microspectrofluorimeter MSF-2 shows as $I_{520}$ and $I_{680}$, respectively, the emission intensity in the green region with maximum $520 \mathrm{~nm}$ and red region with a maximum $680 \mathrm{~nm}$. Lower side: Laserscanning confocal microscopy. Images 5-7 under laser-scanning confocal microscope LSM 510 NLO (5-moistured spore) and Carl Zeiss (6 and 7 developing spore that put off the blue-fluoresced rigid cover-envelope and then divided, resp.). On the scheme of optical image slice under laser-scanning confocal microscope (at the middle of the picture numbers mean cellular parts, from which the appropriate fluorescence spectra have been received with laser-scanning confocal microscope Leica TCS SP-5. By numerals exine (1), its inner layer intine with plasmic membrane (2) and chloroplast (3) are marked. Excitation for the luminescence microscope or microspectrofluorimeter was $420 \mathrm{~nm}$ and for laser-scanning confocal microscopy-405 nm laser. 
TABLE 4: Fluorescence of biologically active compounds (medical drugs) out and within cells of microspores—biosensors. Source: [38, 40].

\begin{tabular}{lcccc}
\hline $\begin{array}{l}\text { Component of plant } \\
\text { secretions with } \\
\text { pharmaceutical features }\end{array}$ & Pure compound & $\begin{array}{c}\text { Fluorescence (color/maxima in nm) } \\
\text { At the interaction with microspores } \\
\text { E. arvense }\end{array}$ & $\begin{array}{c}\text { Cellular } \\
\text { H. hybridum }\end{array}$ & $\begin{array}{c}\text { component- target of a } \\
\text { fluorescent staining }\end{array}$ \\
\hline $\begin{array}{l}\text { Azulene } \\
\text { Atropine }\end{array}$ & Blue/425 & Blue/425, 550 & Blue/425, 550 & Nucleus, chloroplasts \\
d-Tubocurarine & Blue/415 & Blue/465-470 & Blue/465-470 & ChR in Plm \\
Yohimbine & Blue/415 & Blue/425 & Blue/465-475 & ChR, Plm \\
\hline
\end{tabular}

* Plm: plasmalemma, CW: cell wall, ChE: cholinesterase, ChR: cholinoreceptor, AdR: adrenoreceptor, and Glc: glucosidase.

of some natural compounds (including complex secretions) and artificial chemicals. Pollen grains of Hippeastrum hybridum were often used as biosensors [37, 42, 71] as well as a pistil stigma of the same species $[8,24]$. Multicolor pictures received looked as fantastic art photo that makes them fine illustrations $[20,21]$. Besides fluorescent pollens, weak-emitted pollen such as from plantain Plantago major is also used for the analysis of interactions with fluorescent plant secretions, in particular from colored pollen grains) and the action mechanisms of drugs $[8,20-22,40]$.

\subsection{Biosensors in the Study of Chemosignal Processes. Chemo-} signaling is a first process occurred at contacts of sexual and somatic cells. For the studies it is necessary to distinguish two groups of fluorescing objects-cells which serve as donors of fluorescing compounds excreted and cells-acceptors of the chemical signal that are biosensors. Analyzing both cell types the researcher can observe, namely: (1) the changes in natural fluorescence of contacting cells, (2) the penetration of emitted fluorophore into the cell acceptor, (3) binding of the lightening compounds within cells, and (4) quenching or strengthening the total cell-acceptor fluorescence.

Chemosignaling at direct cell-cell contacts is possible to observe, using some sensitive pollen as biosensor (like to study of pollen allelopathy in Section 2.1). Application of LSCM technique permits to observe direct interaction of the contacted pollens and the alterations in their state, basing on the fluorescence changes. In example with LSCM images the secretion released from red-fluorescing pollen of Hypericum perforatum may stain the surface of the color-less pollen from Plantago major $[8,20]$. The fluorescence of slices showed that the red-emitting pigment hypericin concentrated only on the surface without penetration into a cell.

Besides the direct observation of chemosignaling at cellular communications on LSCM-images, there is modelling of the interaction in the system biosensor-contacting chemical. Use of cellular autofluorescence as a response to the chemosignal can be one of the approaches to study mechanisms of action of biologically active substances on sensitive cells $[37,59]$. Cellular mechanisms of the effects of many natural compounds as chemosignals often are not suitable to observe on the tissue slices of animals after vivisection or special conditions of cell storing and cultivation; plant cells have advantages as biosensors. For example, neurotransmitters acetylcholine, catecholamines, serotonin and histamine that also found in excretions of plant and microorganisms $[74,75]$ changed the position of maxima in the emission spectra and intensity of pollen and pistil autofluorescence in Hippeastrum hybridum $[8,24]$ or vegetative microspores of horsetail Equisetum arvense [42]. The neurotransmitters in the presence of other components of secretions-lipids and proteins or membrane-active agents of fungal infectiondecreased or enhanced the fluorescence intensity at $680 \mathrm{~nm}$ of biosensors-vegetative microspores from horsetail Equisetum arvense [42]. Some of the contacted secretory products also fluoresce that allows observing how they interact with unicellular biosensors $[8,21,22,24]$. Fluorescent components of plant secretions are used to study of chemosignal processes at cellular level, stain living cells and provide valuable information about the level of their entering into a cell and binding sites $[21,22]$ as well as the mechanisms of chemoreception and action of some drugs $[40,42,71]$. Bluefluorescent antagonists (blockers of appropriate receptors), in particular antagonist of acetylcholine atropine or d-Tubocurarine and antagonist of catecholamines yohimbine, were binding with plasmatic membrane while histaminic antagonist azulene penetrated into a cell that was seen on LSCM images [42]. Table 4 demonstrates the targets of the compounds' bindings. Antagonists of neurotransmitters are included in secretions of medicinal (allelopathically active) plants as pharmaceuticals with own fluorescence. All compounds studied decreased number of the cells of E. arvense fluorescing in red (Figure 4). d-Tubocurarine and yohimbine did not penetrate the cells binding on the cellular surface, but azulene was linked at both the cell surface and inside the cell, demonstrating blue or blue-green emission. Tubocurarine bound with cholinoreceptor in plasmatic membrane stimulated blue emission and decreased red chlorophyll fluorescence masking plastidal emission. The evidence that tubocurarine and acetylcholine are linked in one and the same site of the membrane is the absence or small blue fluorescence and enhanced red fluorescence in the variant with preliminary treatment of the biosensor cells with acetylcholine.

Besides unicellular microspores, the long-lengthed pistil of Hippeastrum hybridum which the stigma autofluorescence (maxima in the fluorescence spectra and the emission intensity) is sensitive to acetylcholine and histamine as well as their antagonists d-Tubocurarine and azulene $[8,24]$ may be suitable biosensor for the study of chemosignalling. 


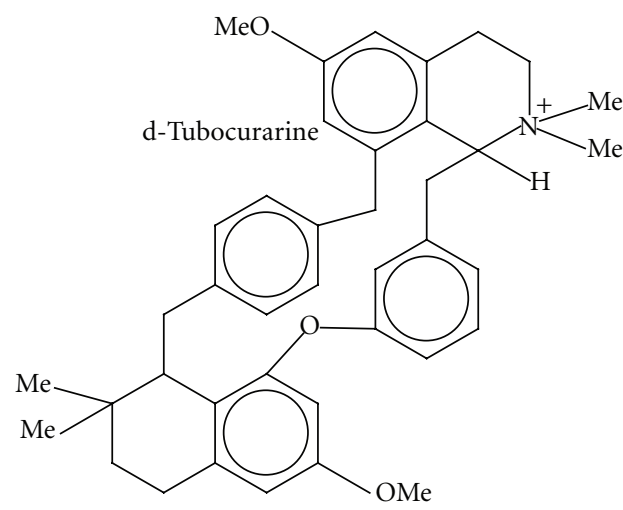

Acetylcholine

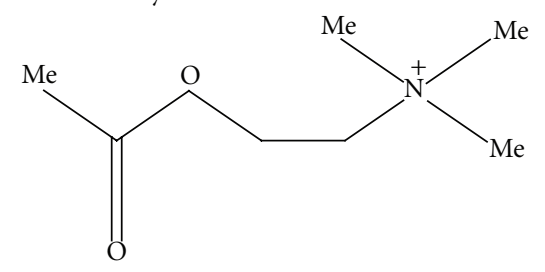

(a)

Blue emission
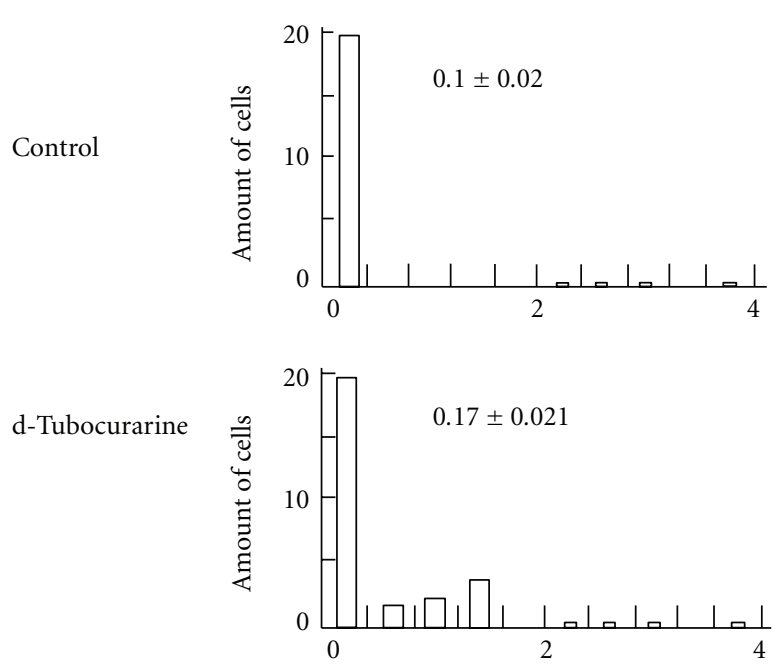

Acetylcholine + d-Tubocurarine

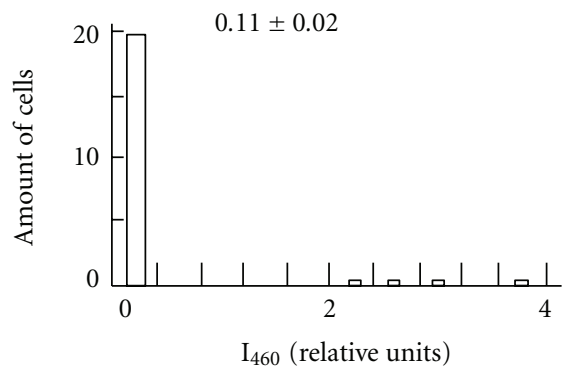

Red emission
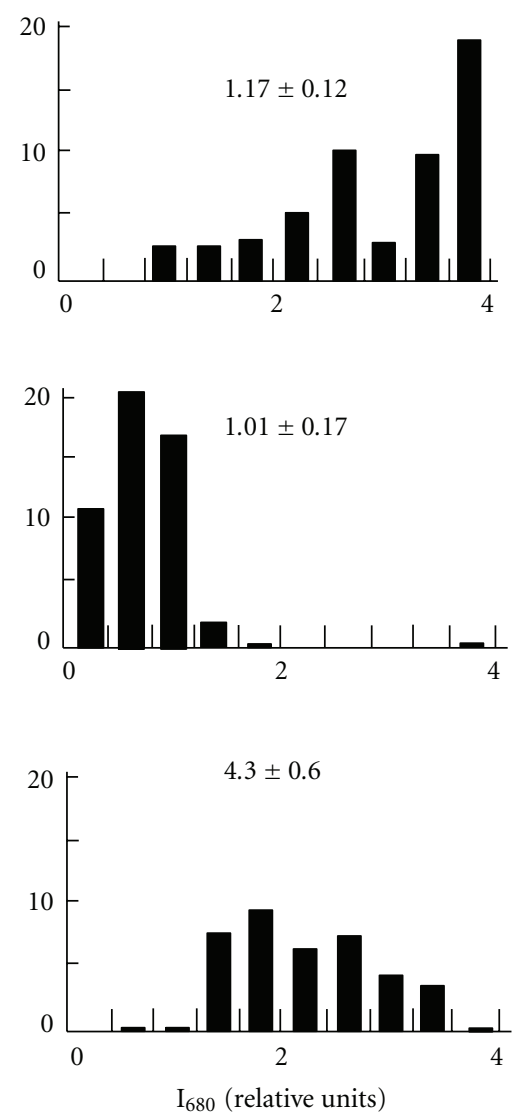

(b)

FIGURE 4: Summed distribution histograms of blue (maximum $460 \mathrm{~nm}$ ) fluorescence intensity of vegetative microspores of horsetail Equisetum arvense before and after the treatment with components of plant secretions during $24 \mathrm{~h}$. Excitation 360-380 nm. Total amount of studied cells in a variant $=100$. Summed values for 100 analyzed cells are also given. 
5.3. Potentials for a Search of New Biosensors. Among potential biosensors may be multicellular systems having autofluorescence. Similar biosensor based on petal fluorescence in flowers such as Mirabilis jalapa may be also applied to analysis of chemosignalling dealt with certain pigmentsfluorophores [60]. The visible fluorescence emitted by one pigment, a yellow betaxanthin, is absorbed by another, a violet betacyanin, to create a contrasting fluorescent pattern on the flower's petals for pollinators. The analysis of free radical processes with the participation of the pigments [76] opened new horizons to search biosensors among pigmented plant cells.

Perspective biosensors today appears to be mycorrhizal roots of plants sensitive to a colonization of arbuscular mycorrhizal fungal structures (such as hyphae, vesicles and spores) that brightly autofluorescence among root tissues under ultraviolet, blue or green light excitation [76-78]. Whole roots of lucerne Medicago sativa may be suitable for the same aim.

\section{Conclusion}

Autofluorescence of living cells may serve as biosensor and bioindicator reaction for various studies of plants-from taxonomic position of plant or pollen viability to the chemosignalling processes. This reaction is analyzed by following ways, namely: (1) on undamaged structures, if their surface composed of fluorescent components or interior of the structures filled of fluorescent secretion; (2) modeling with individual cellular components showing the picture of the fluorescing cellular structure observed. The autofluorescent structure images are studied in a dependence on a purpose either for anatomic characteristics applying to taxonomic sign in plant systematics or for a comparison of samples in the control variants and those that exposed under someone factor. Moreover, optical slices made with laser-scanning confocal microscopy permit to show a location of fluorescing secondary metabolite naturally synthesized within the cell or exometabolite interacted with the cell at cell-cell communications or at experimental addition of the chemical agent. Besides images, the fluorescence spectra of emitted structures may be recorded with microspectrofluorimetry or certain laser-scanning confocal microscopes. Measuring the absorbance and fluorescence spectra there is a possibility to estimate quantitative yield of fluorescence not only for individual fluorophore, but also for certain cells, such as flower petals.

\section{References}

[1] D. L. Taylor and E. D. Salmon, "Basic fluorescence microscopy," in Methods in Cell Biology: Living Cell in Culture, J. L. Wang and D. L. Taylor, Eds., pp. 207-237, Academic Press, San Diego, Calif, USA, 1989.

[2] H. Andersson, T. Baechi, M. Hoechl, and C. Richter, "Autofluorescence of living cells," Journal of Microscopy, vol. 191, no. 1, pp. 1-7, 1998.
[3] O. S. Wolfbeis, "The fluorescence of organic natural products," in Molecular Luminescence Spectroscopy: Methods and Applications, S. G. Schulman, Ed., pp. 167-370, John Wiley \& Sons, New York, NY, USA, 1985.

[4] V. V. Roshchina, "Cellular models to study the allelopathic mechanisms," Allelopathy Journal, vol. 13, no. 1, pp. 3-16, 2004.

[5] V. V. Roshchina, V. A. Yashin, A. V. Yashina, and M. V. Gol'tyaev, "Colored allelochemicals in modelling of cell-cell allelopathic interactions," Allelopathy Journal, vol. 28, no. 1, pp. 1-12, 2011.

[6] C. Pöhlker, J. A. Huffman, and U. Pöschl, "Autofluorescence of atmospheric bioaerosols-fluorescent biomoleculesand potential interferences," Atmospheric Measurement Techniques, vol. 4, no. 5, pp. 5857-5933, 2011.

[7] G. Agati, "Response of the in vivo chlorophyll fluorescence spectrum to environmental factors and laser excitation wavelength," Pure and Applied Optics, vol. 7, no. 4, pp. 797-807, 1998.

[8] V. V. Roshchina, Fluorescing World of Plant Secreting Cells, Science, Enfield, UK, 2008.

[9] M. N. Merzlyak, "Liposoluble fluorescent "aging pigments" in plants," in Lipofuscin-1987: State of the Art, I. Nagy, Ed., pp. 451-452, Akademiai Kiado, Elsevier, Budapest, Amsterdam, The Netherlands, 1988.

[10] V. V. Roshchina, "Autofluorescence of plant secreting cells as a biosensor and bioindicator reaction," Journal of Fluorescence, vol. 13, no. 5, pp. 403-420, 2003.

[11] M. T. M. Willemse, "Autofluorescence of pollen wall of Lilium and changes in pollen wall of Gasteria and Lilium anther," Acta Societatis Botanicorum Poloniae, vol. 50, pp. 103-110, 1981.

[12] M. N. B. M. Driessen, M. T. M. Willemse, and J. A. G. van Luijin, "Grass pollen grain determination by light- and UVmicroscopy," Grana, vol. 28, no. 2, pp. 115-122, 1989.

[13] J. C. Audran and M. T. M. Willemse, "Wall development and its autofluorescence of sterile and fertile Vicia faba L. Pollen," Protoplasma, vol. 110, no. 2, pp. 106-111, 1982.

[14] S. A. Weinbaum and V. S. Polito, "Assessment of pollen retention using exine autofluorescence," Mikroskopie, vol. 42, pp. 278-280, 1985.

[15] V. V. Roshchina, E. V. Melnikova, N. A. Spiridonov, and L. V. Kovaleva, "Azulenes, the blue pigments of pollen," Doklady Biological Sciences, vol. 340, no. 1, pp. 93-96, 1995.

[16] V. V. Roshchina, E. V. Mel'nikova, and L. V. Kovaleva, "Autoflourescence in pollen-pistil system in Hippeastrum hybridum," Doklady Akademii Nauk, vol. 349, no. 1, pp. 118-120, 1996.

[17] V. V. Roshchina, E. V. Mel'nikova, and L. V. Kovaleva, "Changes in fluorescence during development of the male gametophyte," Russian Journal of Plant Physiology, vol. 44, no. 1, pp. 36-44, 1997.

[18] V. V. Roshchina, E. V. Melnikova, L. V. Mit'kovskaya, and V. N. Karnaukhov, "Microspectrofluorimetry for the study of intact plant secreting cells," Zhurnal Obshchei Biologii, vol. 59, no. 5, pp. 531-554, 1998.

[19] V. V. Roshchina and E. V. Melnikova, "Microspectrofluorimetry of intact secreting cells, with applications to the study of allelopathy," in Principles and Practices in Plant Ecology: Allelochemical Interactions, Inderjit, K. M. M. Dakshini, and C. L. Foy, Eds., pp. 99-126, CRC Press, Boca Raton, Fla, USA, 1999.

[20] V. V. Roshchina, A. V. Yashina, and V. A. Yashin, "Cell communication in pollen allelopathy analyzed with laser-scanning confocal microscopy," Allelopathy Journal, vol. 21, no. 2, pp. 219-226, 2008. 
[21] V. V. Roshchina, A. V. Yashina, V. A. Yashin, and N. K. Prizova, "Models to study pollen allelopathy," Allelopathy Journal, vol. 23, no. 1, pp. 3-24, 2009.

[22] V. V. Roshchina, A. V. Yashina, V. A. Yashin, and M. V. Gol'tyaev, "Fluorescence of biologically active compounds in plant secretory cells," in Research Methods in Plant Science, Vol. 2. Forestry and Agroforestry, S. S. Narwal, P. Pavlovic, and J. John, Eds., pp. 3-25, Studium Press, Houston, Tex, USA, 2011.

[23] V. V. Roshchina and E. V. Melnikova, "Microspectrofluorometery: a new technique to study pollen allelopathy," Allelopathy Journal, vol. 3, no. 1, pp. 51-58, 1996.

[24] V. V. Roshchina and E. V. Melnikova, "Chemosensory reactions at the interaction pollen-pistil," Biology Bulletin, no. 6, pp. 678-685, 1998.

[25] A. Salih, A. S. Jones, D. Bass, and G. Cox, "Confocal imaging of exine as a tool for grass pollen analysis," Grana, vol. 36, no. 4, pp. 215-224, 1997.

[26] A. E. Fonseca, M. E. Westgate, and R. T. Doyle, "Application of fluorescence microscopy and image analysis for quantifying dynamics of maize pollen shed," Crop Science, vol. 42, no. 6, pp. 2201-2206, 2002.

[27] V. V. Roshchina and V. N. Karnaukhov, "Changes in pollen autofluorescence induced by ozone," Biologia Plantarum, vol. 42, no. 2, pp. 273-278, 1999.

[28] V. V. Roshchina and E. V. Mel'nikova, "Pollen chemosensitivity to ozone and peroxides," Russian Journal of Plant Physiology, vol. 48, no. 1, pp. 74-83, 2001.

[29] V. V. Roshchina and V. D. Roshchina, Ozone and Plant Cell, Kluwer Academic, Dordrecht, The Netherlands, 2003.

[30] K. Mitsumoto, K. Yabusaki, and H. Aoyagi, "Classification of pollen species using autofluorescence image analysis," Journal of Bioscience and Bioengineering, vol. 107, no. 1, pp. 90-94, 2009.

[31] K. Mitsumoto, K. Yabusaki, K. Kobayashi, and H. Aoyagi, "Development of a novel real-time pollen-sorting counter using species-specific pollen autofluorescence," Aerobiologia, vol. 26, no. 2, pp. 99-111, 2010.

[32] H. Aoyagi and C. U. Ugwu, "Fulerene fine particles adhere to pollen grains and affect their autofluorescence and germination," Nanotechnology, Science and Applications, vol. 4, pp. 6771, 2011.

[33] A. Speranza, R. Crinelli, V. Scoccianti, and A. Geitmann, "Reactive oxygen species are involved in pollen tube initiation in kiwifruit," Plant Biology, vol. 14, no. 1, pp. 64-76, 2011.

[34] A. A. Dobritsa, A. Geanconteri, J. Shrestha et al., "A largescale genetic screen in Arabidopsis to identify genes involved in pollen exine production," Plant Physiology, vol. 157, no. 2, pp. 947-970, 2011.

[35] A. J. Castro, J. D. Rejon, M. Fendri et al., "Taxonomical discrimination of pollen grains by using confocal laser scanning microscopy (CLSM) imaging of autofluorescence," in Microscopy: Science, Technology, Application and Education, A. Mendez-Vilas and J. Diaz, Eds., pp. 607-613, Formatex, Badajoz, Spain, 2010.

[36] M. Suzuzi, M. Tonouchi, K. Muyarama, and K. Mitsumoto, "An analysis of high concentration of pollen at early morning in 2005 spring and a measurement of Japanese cedar and cypress pollen using autofluorescence characteristics," Journal of Aerosol Research, vol. 20, no. 4, pp. 281-289, 2005.

[37] V. V. Roshchina, "Cellular models as biosensors," in Cell Diagnostics: Images, Biophysical and Biochemical Processes in Allelopathy, V. V. Roshchina and S. S. Narwal, Eds., pp. 5-22, Science, Enfield, UK, 2007.
[38] V. V. Roshchina, "Luminescent cell analysis in allelopathy," in Cell Diagnostics: Images, Biophysical and Biochemical Processes in Allelopathy, V. V. Roshchina and S. S. Narwal, Eds., pp. 103115, Science, Enfield, UK, 2007.

[39] V. V. Roshchina, V. A. Yashin, A. V. Kononov, and A. V. Yashina, "Laser-scanning confocal microscopy (LSCM): study of plant secretory cell," in Cell Diagnostics: Images, Biophysical and Biochemical Processes in Allelopathy, V. V. Roshchina and S. S. Narwal, Eds., pp. 93-102, Science, Enfield, UK, 2007.

[40] V. V. Roshchina and V. N. Karnaukhov, "The fluorescence analysis of medicinal drugs' interaction with unicellular biosensors," Farmatsiya, vol. 7, no. 3, pp. 43-46, 2010.

[41] A. G. Valdecasas and A. Abad, "Morphological confocal microscopy in arthropods and the enhancement of autofluorescence after proteinase K extraction," Microscopy and Microanalysis, vol. 17, no. 1, pp. 109-113, 2011.

[42] V. V. Roshchina, V. A. Yashin, and I. M. Vikhlyantsev, "Fluorescence of plant microspores as biosensors," Biochemistry Supplemental Series A, vol. 6, no. 1, pp. 105-112, 2012.

[43] W. Rühland and K. Wetzel, "Der Nachweis von Chloroplasten in den generativen Zellen von Pollenschläuchen," Berirhte Der Deutarhen Botanischen Gesellschaft, vol. 42, pp. 3-14, 1924.

[44] F. Berger, "Das Verhalten der heufieber-erregenden Pollen in filtrien ultravioleten Licht," Beiträge zur Biologie der Pflanzen, vol. 22, no. 1, pp. 1-12, 1934.

[45] F. Asbeck, "Fluorescezieren der Blutenstaub," Naturwissenschaften, vol. 42, no. 5, p. 632, 1955.

[46] P. van Gijzel, "Autofluorescence and age of some fossil pollen and spores," Proceedings of the Koninklijke Nederlandse Akademie Van Wetenschappen-Series B, vol. 64, no. 1, pp. 56-63, 1961.

[47] M. T. M. Willemse, "Morphological and fluorescence microscopical investigation on sporopollenin formation at Pinus sylvestris and Gasteria verrucosa," in Sporopollenin. Proceeding Symposim at Geology Department, Imperial College, London, 1970. 23-25 September, J. Brooks, P. R. Grant, M. Muir, and P. R. van Gijzel, Eds., pp. 68-91, Academic Press, New York, NY, USA, 1971.

[48] D. J. O. 'Connor, D. Iacopino, D. A. Healy, D. O'Sullivan, and J. R. Sodeau, "The intrinsic fluorescence spectra of selected pollen and fungal spores," Atmospheric Environment, vol. 45, no. 35, pp. 6451-6458, 2011.

[49] Y. L. Pan, S. C. Hill, R. G. Pinnick, J. M. House, R. C. Flagan, and R. K. Chang, "Dual-excitation-wavelength fluorescence spectra and elastic scattering for differentiation of single airborne pollen and fungal particles," Atmospheric Environment, vol. 45, no. 8, pp. 1555-1563, 2011.

[50] V. V. Roshchina and V. D. Roshchina, The Excretory Function of Higher Plants, Springer, Berlin, Germany, 1993.

[51] V. V. Roshchina, E. V. Melnikova, V. N. Karnaukhov, and B. N. Golovkin, "Application of microspectrofluorimetry in spectral analysis of plant secretory cells," Biology Bulletin, no. 2, pp. 167-171, 1997.

[52] V. V. Roshchina and E. V. Melnikova, "Spectral analysis of intact secretory cells and excretions of plants," Allelopathy Journal, vol. 2, no. 2, pp. 179-188, 1995.

[53] S. Lee, R. L. Brown, and W. Monroe, "Use of confocal laser scanning microscopy in systematics of insects with a comparison of fluorescence from different stains," Systematic Entomology, vol. 34, no. 1, pp. 10-14, 2009.

[54] Z. Žižka and J. Gabriel, "Primary fluorescence (autofluorescence) of fruiting bodies of the wood-rotting fungus Fomes fomentarius," Folia Microbiologica, vol. 51, no. 2, pp. 109-113, 2006. 
[55] C. H. Wu and H. L. Warren, "Natural autofluorescence in fungi and its correlation with viability," Mycologia, vol. 76, no. 6, pp. 1049-1058, 1984.

[56] C. H. Wu and H. L. Warren, "Induced autofluorescence in fungi, and its correlation with viability: potential application of fluorescence microscopy," Phytopathlogy, vol. 74, no. 6, pp. 1353-1358, 1984.

[57] G. Doehlemann, K. van der Linde, D. Aßmann et al., "Pep1, a secreted effector protein of Ustilago maydis, is required for successful invasion of plant cells," PLoS Pathogens, vol. 5, no. 2, Article ID e1000290, 2009.

[58] A. R. Hardham, "Confocal microscopy in plant-pathogen interactions," in Plant Fungal Pathogens: Methods and Protocols, M. D. D. Bolton, P. H. J. Bart, and P. Thomma, Eds., vol. 835 of Methods in Molecular Biology, pp. 295-309, Springer, Berlin, Germany, 2012.

[59] F. Perrine-Walker, P. Doumas, M. Lucas et al., "Auxin carriers localization drives auxin accumulation in plant cells infected by Frankia in Casuarina glauca actinorhizal nodules," Plant Physiology, vol. 154, no. 3, pp. 1372-1380, 2010.

[60] F. Gandía-Herrero, F. García-Carmona, and J. Escribano, "Botany: floral fluorescence effect," Nature, vol. 437, no. 7057, p. 334, 2005.

[61] P. Hutzler, R. Fischbach, W. Heller et al., "Tissue localization of phenolic compounds in plants by confocal laser scanning microscopy," Journal of Experimental Botany, vol. 49, no. 323, pp. 953-965, 1998.

[62] G. Agati, Z. G. Cerovic, P. Pinelli, and M. Tattini, "Lightinduced accumulation of ortho-dihydroxylated flavonoids as non-destructively monitored by chlorophyll fluorescence excitation techniques," Environmental and Experimental Botany, vol. 73, pp. 3-9, 2011.

[63] G. Conejero, P. Talamond, and J. L. Verdeil, "A new approach to visualize secondary metabolites in plants. Histocytology and plant cell imaging control platform," La plate-forme regionale d'imagerie "Montpellier Rio Imaging" (MRI) organise une journee "Imagerie", Lafayette, La, USA, Octobre 2009, http://phiv.cirad.fr/download/poster.pdf.

[64] A. Iriel and M. G. Lagorio, "Implications of reflectance and fluorescence of Rhododendron indicum flowers in biosignaling," Photochemical and Photobiological Sciences, vol. 9, no. 3, pp. 342-348, 2010.

[65] A. Iriel and M. G. Lagorio, "Is the flower fluorescence relevant in biocommunication?" Naturwissenschaften, vol. 97, no. 10, pp. 915-924, 2010.

[66] F. Gandía-Herrero, J. Escribano, and F. García-Carmona, "Betaxanthins as pigments responsible for visible fluorescence in flowers," Planta, vol. 222, no. 4, pp. 586-593, 2005.

[67] F. Gandía-Herrero, M. Jiménez-Atiénzar, J. Cabanes, J. Escribano, and F. García-Carmona, "Fluorescence detection of tyrosinase activity on dopamine-betaxanthin purified from Portulaca oleracea (common purslane) flowers," Journal of Agricultural and Food Chemistry, vol. 57, no. 6, pp. 2523-2528, 2009.

[68] G. Agati, M. L. Traversi, and Z. G. Cerovic, "Chlorophyll fluorescence imaging for the noninvasive assessment of anthocyanins in whole grape (Vitis Vinifera L.) bunches," Photochemistry and Photobiology, vol. 84, no. 6, pp. 1431-1434, 2008.

[69] D. L. Betemps, J. C. Fachinello, S. P. Galarca et al., "Nondestructive evaluation of ripening and quality traits in apples using a multiparametric fluorescence sensor," Journal of the Science of Food and Agriculture, vol. 92, no. 9, pp. 1855-1864, 2012.
[70] C. Gomez, G. Conejero, L. Torregrosa, V. Cheynier, N. Terrier, and A. Ageorges, "In vivo grapevine anthocyanin transport involves vesicle-mediated trafficking and the contribution of anthoMATE transporters and GST," Plant Journal, vol. 67, no. 6, pp. 960-970, 2011.

[71] V. V. Roshchina, "Plant microspores as biosensors," Trends in Modern Biology, vol. 126, no. 3, pp. 262-274, 2006.

[72] V. V. Roshchina, E. V. Mel'nikova, V. A. Yashin, and V. N. Karnaukhov, "Autofluorescence of intact Equisetum arvense L. spores during their development," Biofizika, vol. 47, no. 2, pp. 318-324, 2002.

[73] V. V. Roshchina, V. A. Yashin, and A. V. Kononov, "Autofluorescence of developing plant vegetative microspores studied by confocal microscopy and microspectrofluorimetry," Journal of Fluorescence, vol. 14, no. 6, pp. 745-750, 2004.

[74] V. V. Roshchina, Neurotransmitters in Plant Life, Science, Enfield, UK, 2001.

[75] V. V. Roshchina, "Evolutionary considerations of neurotransmitters in microbial, plant and animal cells," in Microbial Endocrinology: Interkingdom Signaling in Infectious Disease and Health, M. Lyte and P. P. E. Freestone, Eds., pp. 17-52, Springer, Berlin, Germany, 2010.

[76] R. N. Ames, E. R. Ingham, and C. P. P. Reid, "Ultravioletinduced autofluorescence of a mycorrhizal root infestions and alternative to clearing and staining methods for infections," Canadian Journal of Microbiology, vol. 28, pp. 351-355, 1982.

[77] B. Dreyer, A. Morte, M. Pérez-Gilabert, and M. Honrubia, "Autofluorescence detection of arbuscular mycorrhizal fungal structures in palm roots: an underestimated experimental method," Mycological Research, vol. 110, no. 8, pp. 887-897, 2006.

[78] B. Dreyer, "Use of the autofluorescence properties of AM fungi for AM assessment and handling," Soil Biology, vol. 18, pp. 123-140, 2009. 


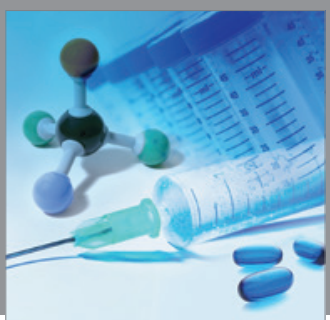

International Journal of

Medicinal Chemistry

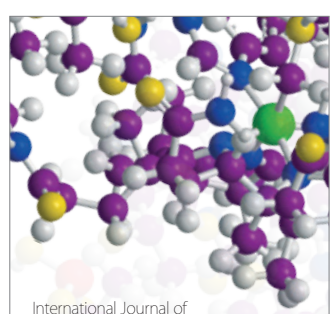

Carbohydrate Chemistry

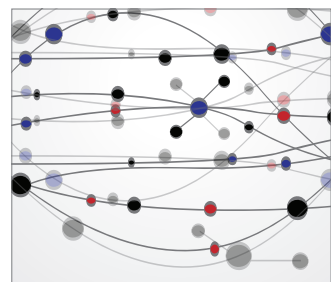

The Scientific World Journal
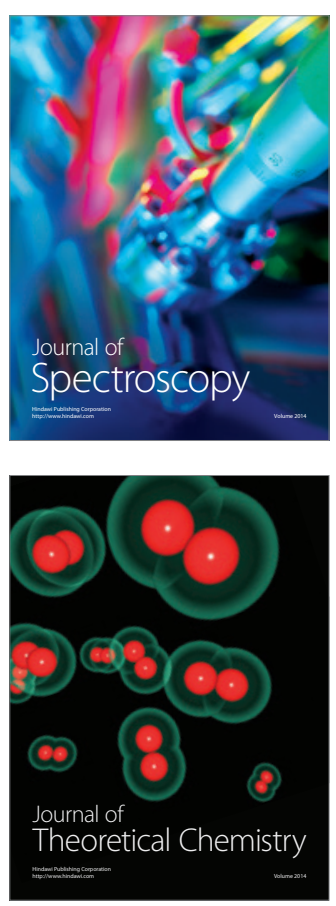
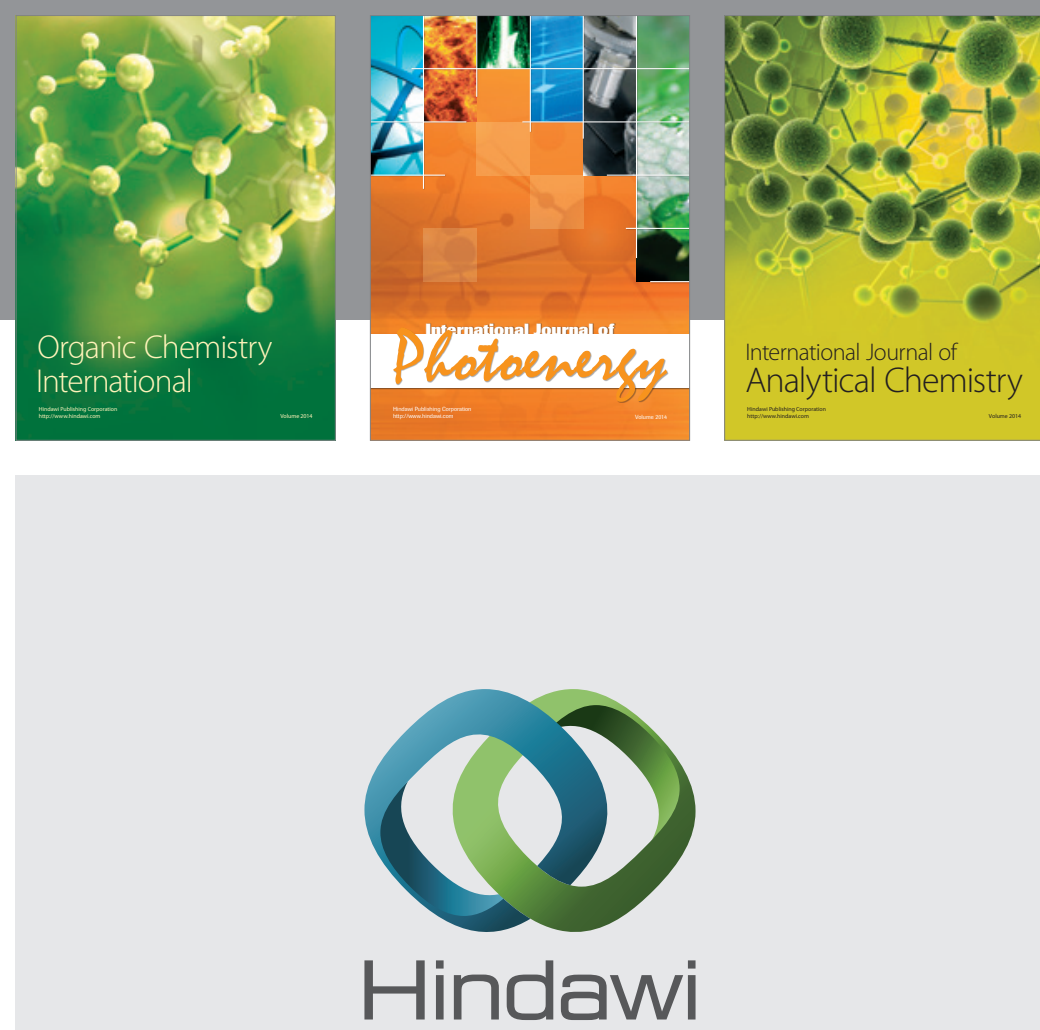

Submit your manuscripts at

http://www.hindawi.com
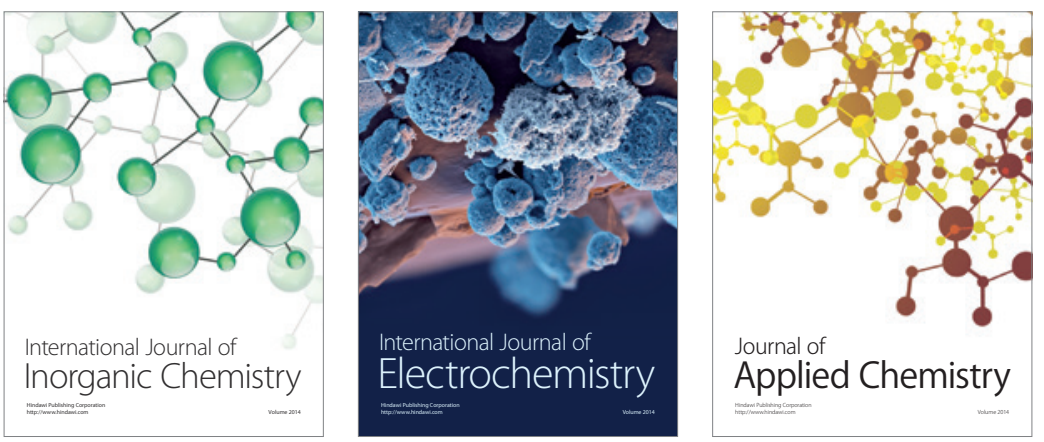

Journal of

Applied Chemistry
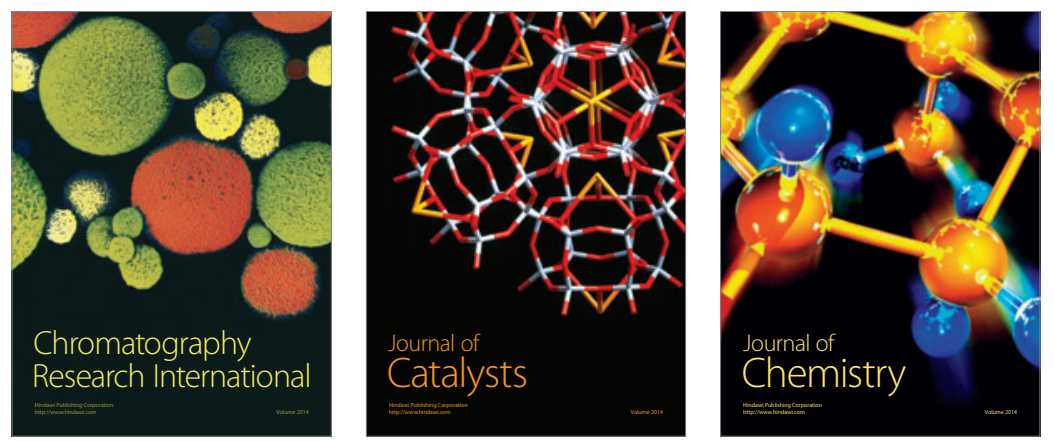
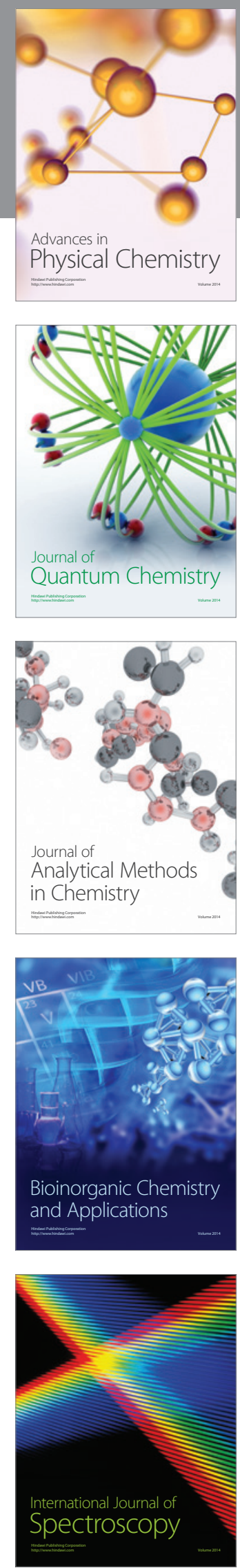